Original research article

Section: Food Quality and Functionality

\title{
Cytoprotective Effect of Morchella esculenta Protein Hydrolysate and Its Derivative Against $\mathrm{H}_{2} \mathrm{O}_{2}$-Induced Oxidative Stress
}

\author{
Qiang Zhang ${ }^{1,2,3}$, Cai-E Wu ${ }^{1,3, *}$, Yu-Jun Sun ${ }^{2}$, Ting-Ting Li ${ }^{1,3}$, Gong-Jian Fan ${ }^{1,3}$ \\ ${ }^{\prime}$ College of Light Industry and Food Engineering, Nanjing Forestry University, Nanjing 210037, China \\ ${ }^{2}$ College of Life and Health Sciences, Anhui Science and Technology University, Fengyang 233100, China \\ ${ }^{3}$ Co-Innovation Center for Sustainable Forestry in Southern China, Nanjing Forestry University, Nanjing 210037, China
}

Key words: Morchella esculenta, protein hydrolysate, Maillard reaction, oxidative stress, cytoprotective effect

Morchella protein hydrolysate (MPH) and its glycosylated derivative (G-MPH) may possess the potential as natural antioxidants. However, knowledge about the protective effects of MPH and G-MPH on cellular oxidative damage is limited. This study evaluated whether MPH and G-MPH protected Caco-2 cells from $\mathrm{H}_{2} \mathrm{O}_{2}$-induced oxidative injury and explored the potential mechanisms of protection. The results showed that, under $\mathrm{H}_{2} \mathrm{O}_{2}$ stress, both MPH and G-MPH significantly increased cell viability, suppressed intracellular ROS and MDA production, increased cellular antioxidant capacity, and activated Nrf2 signaling pathway. More importantly, MPH and G-MPH significantly inhibited the $\mathrm{H}_{2} \mathrm{O}_{2}$-induced apoptosis via restoring the loss of mitochondrial membrane potential and regulating the protein expressions of Bax, Bcl-2, and caspase-3. These data indicate that MPH and G-MPH can protect Caco-2 cells against oxidative injury by improving cellular antioxidant responses and inhibiting apoptosis. Therefore, MPH and G-MPH can have a broad application potential as promising ingredients of nutraceutical products or functional foods.

\section{INTRODUCTION}

It is well known that the production and elimination of reactive oxygen species (ROS) are in a delicate equilibrium in normal cell. Oxidative stress appears when ROS is generated beyond the scavenging capacity of the antioxidant defense system [Zhang et al., 2018d; Zhang et al., 2016]. Oxidative stress caused by excessive ROS production may disrupt the redox homeostasis, induce autophagy, trigger apoptosis, and cause irreversible tissue injury [Shen et al., 2017]. It has been confirmed that the damages caused by oxidative stress can lead to many chronic diseases such as cancer, diabetes, cardiovascular diseases, and neurodegenerative diseases [Wang et al., 2015; Zhang et al., 2016]. Therefore, how to protect the cell against oxidative stress-induced injury and enhance the cellular and tissue defenses against ROS require more attention.

Dietary intake of natural antioxidants has been demonstrated as a feasible way to eliminate the harmful effects of ROS and restore the body's antioxidant load [Seifried et al., 2007]. Hence, there is an increasing interest on natural antioxidants to prevent chronic diseases caused by oxidative stress. Food-derived protein hydrolysate, produced by the enzymatic hydrolysis of natural food proteins, is one of the numerous natural antioxidants. Due to a high antioxidant ac-

\footnotetext{
* Corresponding Author: Tel.: Tel.: +86-02585427844;

E-mail: wucaie@njfu.edu.cn (Prof. CaiE Wu)
}

tivity, satisfactory safety, and bioavailability, food-derived protein hydrolysates have received significant scientific attention in the food industry and healthcare field [Jin et al., 2013; Morifuji et al., 2010]. Protein hydrolysates from soybean [Zhang et al., 2018d], common carp [Zamora-Sillero et al., 2018], wheat germ [Zhou et al., 2016], and rice dreg [Zhang et al., 2016], exhibited potential in vitro antioxidant activity in chemical models or cell models. Additionally, our previous studies demonstrated that the protein hydrolysate (MPH) from Morchella esculenta (L.), an edible and medicinal fungus of high economic value, exhibited various antioxidant properties such as excellent reducing power, efficient free radical scavenging activity, and considerable $\mathrm{H}_{2} \mathrm{O}_{2}$ scavenging activity. Moreover, the glycosylated derivative of MPH (G-MPH) produced by conjugating with xylose via Maillard reaction exhibited higher antioxidant properties than MPH [Zhang et al., 2018b]. However, to the best of our knowledge, the cytoprotective effect of MPH and G-MPH against oxidative stress and its underlying mechanisms have never been reported.

It has been widely acknowledged that the nuclear factor erythroid 2-related factor 2 (Nrf2) signaling pathway is a key mediator in oxidative stress [Li et al., 2017]. Under normal conditions, Nrf2 binds to Kelch-like ECH-associated protein 1 (Keap1) in the cytoplasm to form a complex. To counteract oxidative stress, Nrf2 is released from Keap1 before being translocated into the nucleus, binds to the antioxidantresponse elements (AREs), and promotes the expression of downstream genes including haeme oxygenase-1 (HO-1), 
$\mathrm{NAD}(\mathrm{P}) \mathrm{H}$ :quinone oxidoreductase 1 (NQO1), and some antioxidant enzymes such as superoxide dismutase (SOD) and catalase (CAT) [Pyo et al., 2016; Xia et al., 2017]. These enzymes play a role in cell detoxification and maintenance of antioxidant capacity which in turn help regulate the redox balance [Xia et al., 2017]. It has been reported that Maillard reaction products of fish protein hydrolysate and ribose activate Nrf2 to protect HepG2 cells against oxidative stress [Yang et al., 2017]. Therefore, it is hypothesized that MPH and G-MPH may attenuate the $\mathrm{H}_{2} \mathrm{O}_{2}$-induced oxidative injury, potentially via the activation of Nrf2 signaling pathway.

Apoptosis (programmed cell death) plays an important role in regulating numerous physiological processes such as growth, development, and homeostasis maintenance [Mańdziuk et al., 2003]. Imbalance between cell proliferation and apoptosis can cause pathological phenomena such as cancer and Alzheimer's disease [Yoon et al., 2001]. Many reports have demonstrated that various natural antioxidants protect cells from oxidative damage by suppressing apoptosis [Chen et al., 2017; Zhou et al., 2016]. However, whether the underlying mechanisms by which MPH and G-MPH exert cytoprotective effects against oxidative damage is via apoptosis inhibition or not remains unclear.

The aim of this study was thus to evaluate the cytoprotective effects of MPH and G-MPH against oxidative stress using Caco-2 cells, which is an ideal tool to assess the cellular antioxidant response to food-derived antioxidants [Ruiz-Roca et al., 2011]. Moreover, we investigated whether MPH and G-MPH exert cytoprotective effects by activating Nrf2 signaling pathway and by inhibiting apoptosis in an attempt to explain its underlying molecular mechanisms.

\section{MATERIALS AND METHODS}

\section{Reagents}

The cell culture reagents were obtained from Gibco BRL Life Technologies (USA). Malondialdehyde (MDA), glutathione (GSH), total antioxidant capacity (T-AOC), superoxide dismutase (SOD), and catalase (CAT) kits were purchased from Nanjing Jiancheng Bioengineering Institute (Nanjing, China). Kits for ROS assay, Annexin V-FITC detection, TUNEL assay, JC-1 assay, total protein extraction and quantification, and enhanced chemoluminescence (ECL) detection were purchased from Keygen Biotech Co., Ltd. (Nanjing, China). All primary and secondary antibodies were obtained from Santa Cruz Biotechnology (Santa Cruz, CA). All other reagents, unless otherwise stated, were purchased from Sigma-Aldrich.

\section{Preparation of MPH and G-MPH}

The strain of M. esculenta (ACCC 50537) used in this study was purchased from the Agricultural Culture Collection of China. Morchella protein was produced by alkaline extraction followed by acidic precipitation from Morchella mycelium obtained by liquid fermentation according to our previously described method [Zhang et al., 2018c]. Briefly, the Morchella mycelia were homogenized and the proteins were extracted with $\mathrm{NaOH}$ solution $(\mathrm{pH} 12.0)$ by incubating in a water bath at $45^{\circ} \mathrm{C}$ for $1 \mathrm{~h}$. The solution was centri- fuged at $4,000 \times g$ for $20 \mathrm{~min}$, the supernatant was adjusted to $\mathrm{pH} 4.1$ with $2 \mathrm{~mol} / \mathrm{L} \mathrm{HCl}$, and further centrifuged at $4,000 \times g$ for $20 \mathrm{~min}$. After removing the supernatant, the precipitate was lyophilized to obtain the Morchella protein.

MPH and G-MPH were prepared based on our previous report [Zhang et al., 2018b]. Briefly, the Morchella protein was hydrolyzed using papain at an enzyme/protein ratio of $2 \%$ in a shaking water bath at $45^{\circ} \mathrm{C}$ for $3 \mathrm{~h}$, at $\mathrm{pH} 6.0$. Subsequently, the enzyme was inactivated in a boiling water bath for $10 \mathrm{~min}$, followed by centrifugation at $4,000 \times g$ for $15 \mathrm{~min}$. The supernatant was lyophilized to obtain MPH. G-MPH was produced by the Maillard reaction. MPH was mixed with xylose at a mass ratio of 1:3.7 in distilled water, adjusted to $\mathrm{pH} 11.8$, and incubated in a boiling water bath for $60 \mathrm{~min}$. The resulting solution was dialyzed (molecular weight cut-off, $200 \mathrm{Da}$ ) against distilled water for $48 \mathrm{~h}$ to remove unreacted xylose and the retentate was freeze-dried to obtain G-MPH. The MPH and G-MPH have been preliminarily characterized by infrared spectroscopy, fluorescence spectroscopy, and scanning electron microscopy in our previous study [Zhang et al., 2018a] .

\section{Cell culture and treatment}

Caco-2 cells were obtained from the Cell Bank of Type Culture Collection of Chinese Academy of Sciences (Shanghai, China). Caco-2 cells were cultured in DMEM medium containing $10 \%$ FBS and $1 \%$ streptomycin/penicillin at $37^{\circ} \mathrm{C}$ in a humidified 5\% $\mathrm{CO}_{2}$ incubator. To explore the protective effects of MPH and G-MPH against $\mathrm{H}_{2} \mathrm{O}_{2}$-induced oxidative stress, cells were grouped as follows: control group (Caco-2 cells without any treatment), model group (Caco-2 cells treated with $300 \mu \mathrm{M} \mathrm{H}_{2} \mathrm{O}_{2}$ for $6 \mathrm{~h}$ ), MPH group (Caco-2 cells pretreated with $250 \mu \mathrm{g} / \mathrm{mL}$ MPH for $1 \mathrm{~h}$ followed by incubation with $300 \mu \mathrm{M} \mathrm{H}_{2} \mathrm{O}_{2}$ for $6 \mathrm{~h}$ ), G-MPH group (Caco-2 cells pretreated with $250 \mu \mathrm{g} / \mathrm{mL}$ G-MPH for $1 \mathrm{~h}$ followed by incubation with $300 \mu \mathrm{M} \mathrm{H}_{2} \mathrm{O}_{2}$ for $6 \mathrm{~h}$ ), and Vc group (Caco-2 cells pretreated with $250 \mu \mathrm{g} / \mathrm{mL} \mathrm{Vc}$ for $1 \mathrm{~h}$ followed by incubation with $300 \mu \mathrm{M} \mathrm{H}_{2} \mathrm{O}_{2}$ for $6 \mathrm{~h}$ ).

\section{Cell viability assay}

Cell viability was determined by 3-(4,5-dimethyl2-thiazoyl)-2,5-diphenyl-2H-tetrazolium bromide (MTT) assay. Briefly, Caco-2 cells $\left(1 \times 10^{5} / \mathrm{mL}\right)$ were seeded in 96 -well plates (100 $\mu \mathrm{L}$ culture media/well), the cultures were maintained at $37^{\circ} \mathrm{C}$ for $24 \mathrm{~h}$ in a humidified $5 \% \mathrm{CO}_{2}$ incubator, and treated with specified concentrations of ligands for designated time. After the treatment, $20 \mu \mathrm{L}$ of MTT $(5 \mathrm{mg} / \mathrm{mL})$ solution was added to each well and incubated for $3 \mathrm{~h}$ at $37^{\circ} \mathrm{C}$. Thereafter, the supernatant was discarded from the wells, washed with phosphate-buffered saline (PBS; $1 \times$, $\mathrm{pH}$ 7.4), and $150 \mu \mathrm{L}$ of dimethyl sulfoxide (DMSO) was added to each well. The plates were placed on a shaker for $10 \mathrm{~min}$ and the absorbance was measured at $490 \mathrm{~nm}$ with an ELx800 microplate reader (Bio-Tek, USA).

\section{Measurement of intracellular ROS}

Intracellular ROS levels were detected using 2',7'-dichlorofluorescein diacetate (DCFH-DA), a cell permeable nonfluorescent probe. After experimental treatment, the cells were 
washed once with PBS, harvested, incubated with $10 \mu \mathrm{M}$ DCFH-DA (diluted with serum-free culture media) at $37^{\circ} \mathrm{C}$ for $20 \mathrm{~min}$, and washed three times with a serum-free cell culture solution. The fluorescence was measured by flow cytometry at $\lambda e x=488 \mathrm{~nm}$ and $\lambda e \mathrm{em}=530 \mathrm{~nm}$.

\section{Determination of MDA and GSH contents, T-AOC, and SOD and CAT activities}

After the experimental treatment, cells were washed once with PBS, harvested, lysed in $1000 \mu \mathrm{L}$ of cold PBS by sonication, and centrifuged at $13,000 \times g$ for $10 \mathrm{~min}$ at $4^{\circ} \mathrm{C}$. The resulting supernatant was used for subsequent measurements. Total protein was quantified by a BCA protein assay kit. MDA and GSH contents, T-AOC, and SOD and CAT activities were detected using the commercial kits according to manufacturer's instructions. Each experiment was repeated 3 times. MDA and GSH are expressed as $\mu \mathrm{mol} / \mathrm{g}$ protein and T-AOC, SOD, and CAT as U/mg protein.

\section{Immunofluorescence staining}

After the experimental treatment, the culture media were carefully discarded; the cells were washed three times with PBS and fixed with $4 \%$ paraformaldehyde at room temperature for $30 \mathrm{~min}$. Cells were then washed with PBS (3 washes of $10 \mathrm{~min}$ each) and endogenous peroxidases were blocked with $3 \% \mathrm{H}_{2} \mathrm{O}_{2}$-methanol solution for $10 \mathrm{~min}$. Cells were then washed with PBS (3 washes of 10 min each), blocked with $10 \%$ goat serum for $20 \mathrm{~min}$, followed by incubating with primary anti-Nrf2 antibody $(1: 100)$ at $37^{\circ} \mathrm{C}$ for $2 \mathrm{~h}$. Cells were then washed with PBS (3 washes of $10 \mathrm{~min}$ each) and incubated with fluorescein isothiocyanate (FITC) conjugated secondary antibody (1:200 dilution) at $37^{\circ} \mathrm{C}$ for $1 \mathrm{~h}$. After washing 3 times with PBS, nuclei were stained with 4',6-diamidino2-phenylindole (DAPI) at room temperature for $5 \mathrm{~min}$ in the dark. Stained cells were washed with PBS (3 washes of $10 \mathrm{~min}$ each) and blotted to remove any residual liquid. Cells were mounted onto glass slides with antifade mounting medium and were analyzed using an inverted fluorescence microscope (Olympus IX51, Japan).

\section{TUNEL assay}

Apoptotic cells were detected using TUNEL assay kit following the manufacturer's protocol. Briefly, after the experimental treatment, the cells were fixed in $4 \%$ paraformaldehyde for $30 \mathrm{~min}$ and washed three times with PBS. The cells were permeabilized with $1 \%$ Triton X-100 for 15 min at room temperature and rinsed three times with PBS. The cells were then incubated with $100 \mu \mathrm{L}$ of TUNEL reaction mixture at $37^{\circ} \mathrm{C}$ for $60 \mathrm{~min}$, rinsed three times with PBS, and stained with $100 \mu \mathrm{L}$ of DAPI solution at $37^{\circ} \mathrm{C}$ in the dark for $5 \mathrm{~min}$. The apoptotic cells were observed under an inverted fluorescence microscope (Olympus IX51, Japan).

\section{Annexin V-FITC/PI double staining assay}

Apoptotic cells were quantified using the Annexin V-FITC/PI apoptosis detection kit. After the experimental treatment, cells were harvested by trypsinization and washed twice with PBS. Then, the cells were collected by centrifugation at $1000 \times g$ for $5 \mathrm{~min}$ and approximately $5 \times 10^{5}$ cells were resuspended in $500 \mu \mathrm{L}$ of binding buffer. They were then incubated with $5 \mu \mathrm{L}$ of Annexin V-FITC and $5 \mu \mathrm{L}$ of propidium iodide (PI) at room temperature for $15 \mathrm{~min}$ in the dark prior to flow cytometry (Becton Dickinson FACSCalibur).

\section{Measurement of mitochondrial transmembrane potential (MMP)}

JC-1 assay kit was used to detect MMP according to manufacturer's instructions. Briefly, Caco-2 cells from different treatments were rinsed with $1 \times$ incubation buffer and incubated with $0.5 \mathrm{~mL}$ of JC-1 working solution at $37^{\circ} \mathrm{C}$ for $20 \mathrm{~min}$ in the dark. After rinsing twice with $1 \times$ incubation buffer, the cells were resuspended in $0.5 \mathrm{~mL}$ of $1 \times$ incubation buffer and the cell fluorescence was detected with a flow cytometer (Becton Dickinson FACSCalibur) $(\lambda e x=488 \mathrm{~nm}$, $\lambda \mathrm{em}=530 \mathrm{~nm})$. Data analysis was performed using CellQuest software (Becton-Dickinson).

\section{Western blot analysis}

Total proteins from Caco-2 cells were extracted with a total protein extraction kit and quantified using the BCA protein assay kit. After separation by SDS-PAGE (12\%), proteins were transferred onto nitrocellulose (NC) membrane at $300 \mathrm{~mA}$ for $90 \mathrm{~min}$, saturated with a blocking solution containing $5 \%$ non-fat milk for $1.5 \mathrm{~h}$, and incubated with appropriate primary antibodies overnight at $4^{\circ} \mathrm{C}$. The membranes were washed three times (10 min each) with TBST (Tris-buffered saline and Tween) and incubated with secondary antibody for $1.5 \mathrm{~h}$ at room temperature. The protein bands were visualized on a gel imaging system (Syngene G: BOXChemiXR5, Cambridge, UK) using an ECL kit. The relative protein expression levels were quantitated by the Gel-Pro32 software (MediaCybernetics Inc., USA) and normalized with GAPDH.

\section{Quantitative real-time PCR (qPCR) analysis}

Total RNA was extracted from the treated Caco-2 cells using Trizol reagent (Invitrogen, USA) according to the manufacturer's protocol. RNA concentration was measured and quality was detected by measuring the absorbance at 260 and $280 \mathrm{~nm}$ using a UV-vis spectrophotometer (Shimadzu UV-2450). cDNA was synthesized in a $20-\mu \mathrm{L}$ reaction volume from $2 \mu \mathrm{g}$ of total RNA using the Reverse Transcription kit (K1622; Thermo Fisher Scientific). The qPCR reactions were performed with SYBR ${ }^{\circledR}$ Premix Ex TaqTM II (TaKaRa, Dalian, China) on a StepOnePlus Real-Time PCR System (Applied Biosystems, USA). Primer sequences were as follows: Nrf2, F: 5'-CAACTACTCCCAGGTTGCCC-3', R: 5'-AGTGACTGAAACGTAGCCGAA-3'; NQO1, F: 5'-GCTGCCATGTATGACAAAGGAC-3', R: 5'-CATGTCCCCGTGGATCCCTT-3'; HO-1, F: 5'-TCTTGGCTGGCTTCCTTACC-3', R: 5'-GGATGTGCTTTTCGTTGGGG-3'; GAPDH, F:5'-TGTTGCCATCAATGACCCCTT-3', andR:5'-CTCCACGACGTACTCAGCG-3'. The gene expression data were normalized to the housekeeping gene (GAPDH) and expressed as $2^{-\Delta \Delta \mathrm{CT}}$ values.

\section{Statistical analysis}

Data are represented as mean $\pm \mathrm{SD}$ of triplicate experiments. Data were analyzed by one-way ANOVA using 

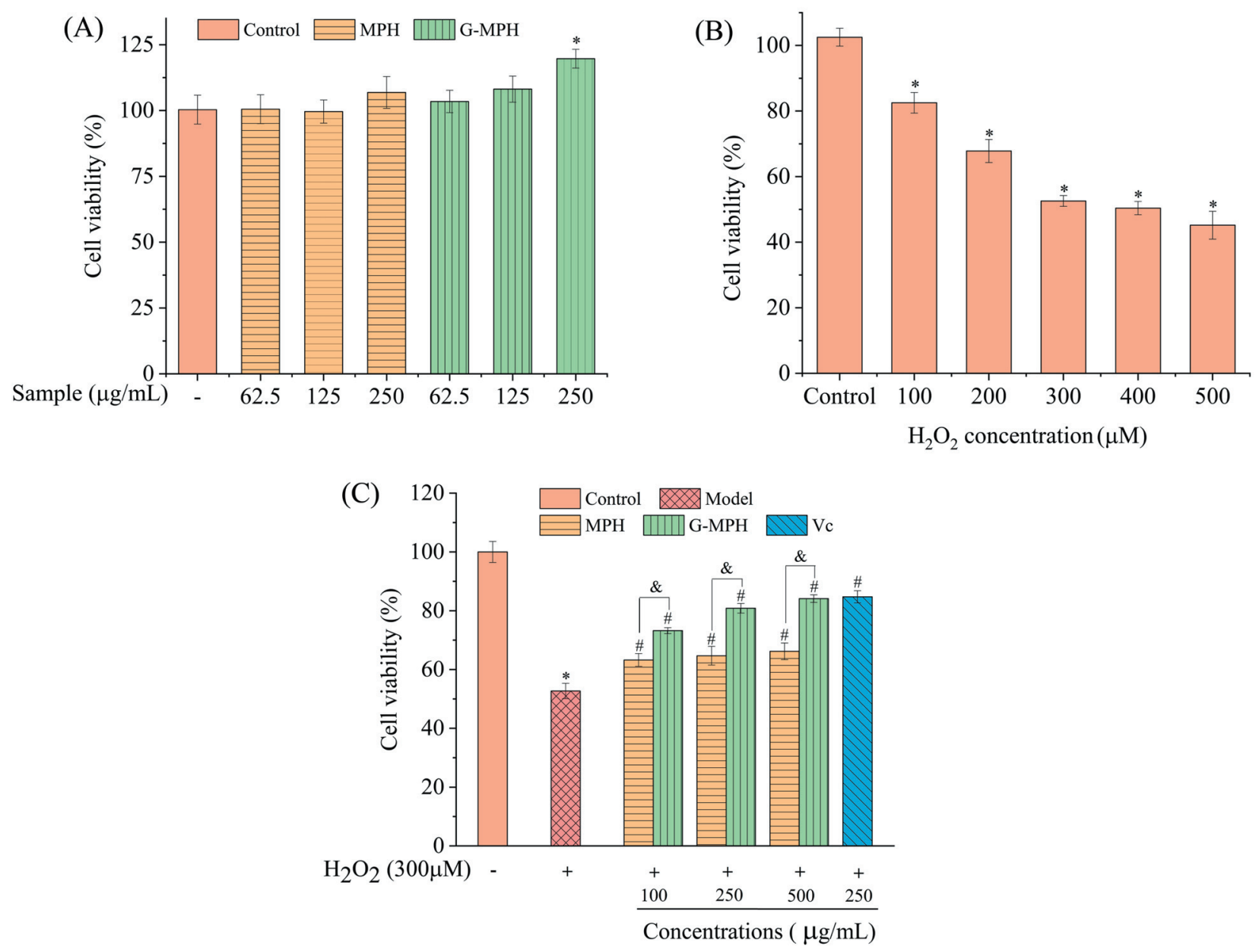

FIGURE 1. Protective effects of MPH and G-MPH against $\mathrm{H}_{2} \mathrm{O}_{2}$-induced cytotoxicity in Caco-2 cells. (A) Cells treated with various concentrations of MPH or G-MPH for $7 \mathrm{~h}$. (B) Cells treated with different concentrations of $\mathrm{H}_{2} \mathrm{O}_{2}$ for $6 \mathrm{~h}$. (C) Cells incubated with various concentrations of MPH or G-MPH for $1 \mathrm{~h}$ before exposure to $300 \mu \mathrm{M} \mathrm{H}_{2} \mathrm{O}_{2}$ for $6 \mathrm{~h}$. Vc at a concentration of $250 \mu \mathrm{g} / \mathrm{mL}$ was used as a positive control. Cell viability was quantified by MTT assay. The data are presented as means $\pm \mathrm{SD}, \mathrm{n}=3 .{ }^{*} p<0.05$ versus control, ${ }^{*} p<0.05$ versus model, ${ }^{*} p<0.05$ versus MPH. MPH - Morchella protein hydrolysate; G-MPH - glycosylated derivative of MPH.

SPSS 19.0. The differences between groups were performed by Duncan's multiple range test and considered statistically significant at $p<0.05$.

\section{RESULTS AND DISCUSSION}

MPH and G-MPH protected Caco-2 cells from $\mathrm{H}_{2} \mathrm{O}_{2}-$ -induced injury

To examine the cytotoxic potential of MPH, G-MPH, and $\mathrm{H}_{2} \mathrm{O}_{2}$, cell viability of Caco-2 cells under different treatments was measured by MTT assay. MPH and G-MPH had no negative effects at the tested concentrations $(62.5-250 \mu \mathrm{g} /$ $\mathrm{mL})$ (Figure 1A). However, $\mathrm{H}_{2} \mathrm{O}_{2}(100-500 \mu \mathrm{M})$ significantly $(p<0.05)$ decreased cell viability after incubating for $6 \mathrm{~h}$ in a concentration-dependent manner (Figure 1B). At a concentration of $300 \mu \mathrm{M}, \mathrm{H}_{2} \mathrm{O}_{2}$ moderately decreased cell viability $(52.58 \%)$. Therefore, the cells were treated with $300 \mu \mathrm{M}$ $\mathrm{H}_{2} \mathrm{O}_{2}$ for $6 \mathrm{~h}$ in the following experiments.

Next, we evaluated the protective effects of MPH and GMPH against $\mathrm{H}_{2} \mathrm{O}_{2}$-induced oxidative injury. As shown in Figure 1C, exposure of Caco-2 cells to $300 \mu \mathrm{M} \mathrm{H}_{2} \mathrm{O}_{2}$ for $6 \mathrm{~h}$ decreased cell viability by $47.31 \%$ compared to the con- trol group, whereas pretreatment with MPH and G-MPH both significantly ameliorated the decrease in cell viability $(p<0.05)$; G-MPH showed significantly more protective effect on cell proliferation than MPH $(p<0.05)$. The protective effect of $500 \mu \mathrm{g} / \mathrm{mL}$ G-MPH was almost the same as that of $250 \mu \mathrm{g} / \mathrm{mL} \mathrm{Vc}$. This result implies that MPH and G-MPH can attenuate $\mathrm{H}_{2} \mathrm{O}_{2}$-induced cytotoxicity and exhibit significant protective effects against $\mathrm{H}_{2} \mathrm{O}_{2}$-induced oxidative injury. Furthermore, both MPH and G-MPH at 250 and $500 \mu \mathrm{g} / \mathrm{mL}$ concentrations caused similar protective effects. Therefore, $250 \mu \mathrm{g} / \mathrm{mL}$ was selected as the optimal concentration (MPH and G-MPH) in $\mathrm{H}_{2} \mathrm{O}_{2}$-treated Caco-2 cells for subsequent experiments. Similar study was conducted by Zha et al. [2015] who reported that neither the shrimp by-product protein hydrolysate nor its glycosylated derivative had any cytotoxic effect at $1000 \mu \mathrm{g} / \mathrm{mL}$ concentration, but protected human HepG2 cells against AAPH-induced oxidative injury.

\section{MPH and G-MPH inhibited $\mathrm{H}_{2} \mathrm{O}_{2}$-induced $\mathrm{ROS}$ generation and lipid peroxidation in Caco-2 cells}

Growing evidences support that oxidative damage plays a crucial role in the pathophysiology of various diseases [Fer- 

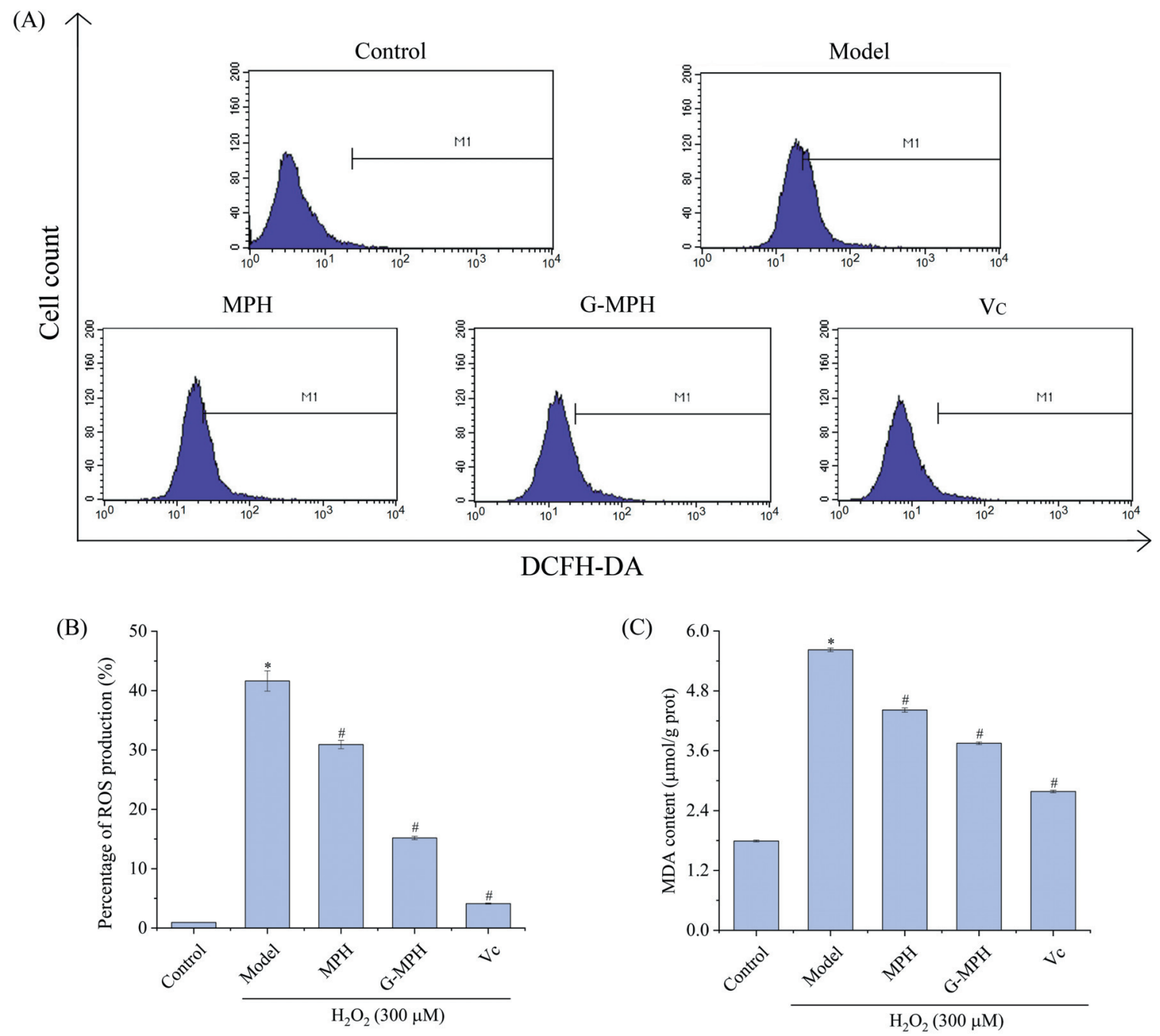

FIGURE 2. Effects of MPH and G-MPH on ROS generation and lipid peroxidation by $\mathrm{H}_{2} \mathrm{O}_{2}$ in Caco-2 cells. (A) and (B) ROS identified using DCFHDA staining combined with flow cytometry and the corresponding data quantified. (C) Lipid peroxidation assessed by MDA assay. Data are means \pm SD from 3 independent experiments. ${ }^{*} p<0.05$ versus control, ${ }^{*} p<0.05$ versus model. MPH - Morchella protein hydrolysate; G-MPH - glycosylated derivative of MPH.

nandez-Checa et al., 2010]. When the body is under oxidative stress, there is a shift in the redox balance between oxidants and antioxidants, resulting in an increase in the amount of ROS in the cells [Mariani et al., 2005]. Excessive ROS can cause oxidation of proteins and lipids in cells, destroying the integrity of nuclear DNA and mitochondria, and ultimately leading to cell death [Yamaguchi et al., 2015]. The levels of ROS in Caco-2 cells were detected by DCFH-DA probe combined with flow cytometry. As shown in Figure 2A to B, $\mathrm{H}_{2} \mathrm{O}_{2}$ treatment notably increased production of ROS in Caco-2 cells compared to control. However, pretreatment with MPH, G-MPH, or Vc significantly reduced $\mathrm{H}_{2} \mathrm{O}_{2}$-induced $\mathrm{ROS}$ generation and the ROS levels in Caco-2 cells reduced to $30.92 \pm 0.71 \%, 15.18 \pm 0.29 \%$, and $4.12 \pm 0.09 \%$, respectively, which were significantly lower than that in the model group $(p<0.05)$.

Lipid peroxidation is one of the major events in free radical-induced cell oxidative damage. MDA, a major by-product of membrane lipid peroxidation, is considered as a biomarker of cell membrane injury. MDA can further amplify the effect of ROS causing a cascade of chain reactions, destroying biological macromolecules such as nucleic acids and proteins, and causing various diseases in the body [Je \& Lee, 2015; Lee et al., 2004]. The effects of MPH and G-MPH on intracellular MDA levels are presented in Figure 2C. Along with ROS generation, MDA level in model group was also significantly more than that in the control group $(p<0.05)$. Pretreatment with $\mathrm{MPH}, \mathrm{G}-\mathrm{MPH}$, or Vc significantly attenuated $\mathrm{H}_{2} \mathrm{O}_{2}$-induced MDA production $(p<0.05)$. Collectively, these results reveal that MPH and G-MPH may prevent the formation of ROS, inhibit lipid peroxidation, and accordingly protect the cells from $\mathrm{H}_{2} \mathrm{O}_{2}$-induced oxidative damage. These findings are similar to the earlier study which reported the antioxidative activities of rice dreg protein hydrolysate [Zhang et al., 2016]. The protective effect may be due to the wide range of antioxidant activities MPH and G-MPH possess and the roles they play as $\mathrm{H}_{2} \mathrm{O}_{2}$ and free radical scavengers, which have been confirmed in our previous studies [Zhang et al., 2018b].

\section{MPH and G-MPH enhanced antioxidant defense capacity of $\mathrm{H}_{2} \mathrm{O}_{2}$-treated Caco- 2 cells}

There are both enzyme and non-enzyme antioxidant defense systems in the body. Excess ROS in the body is con- 

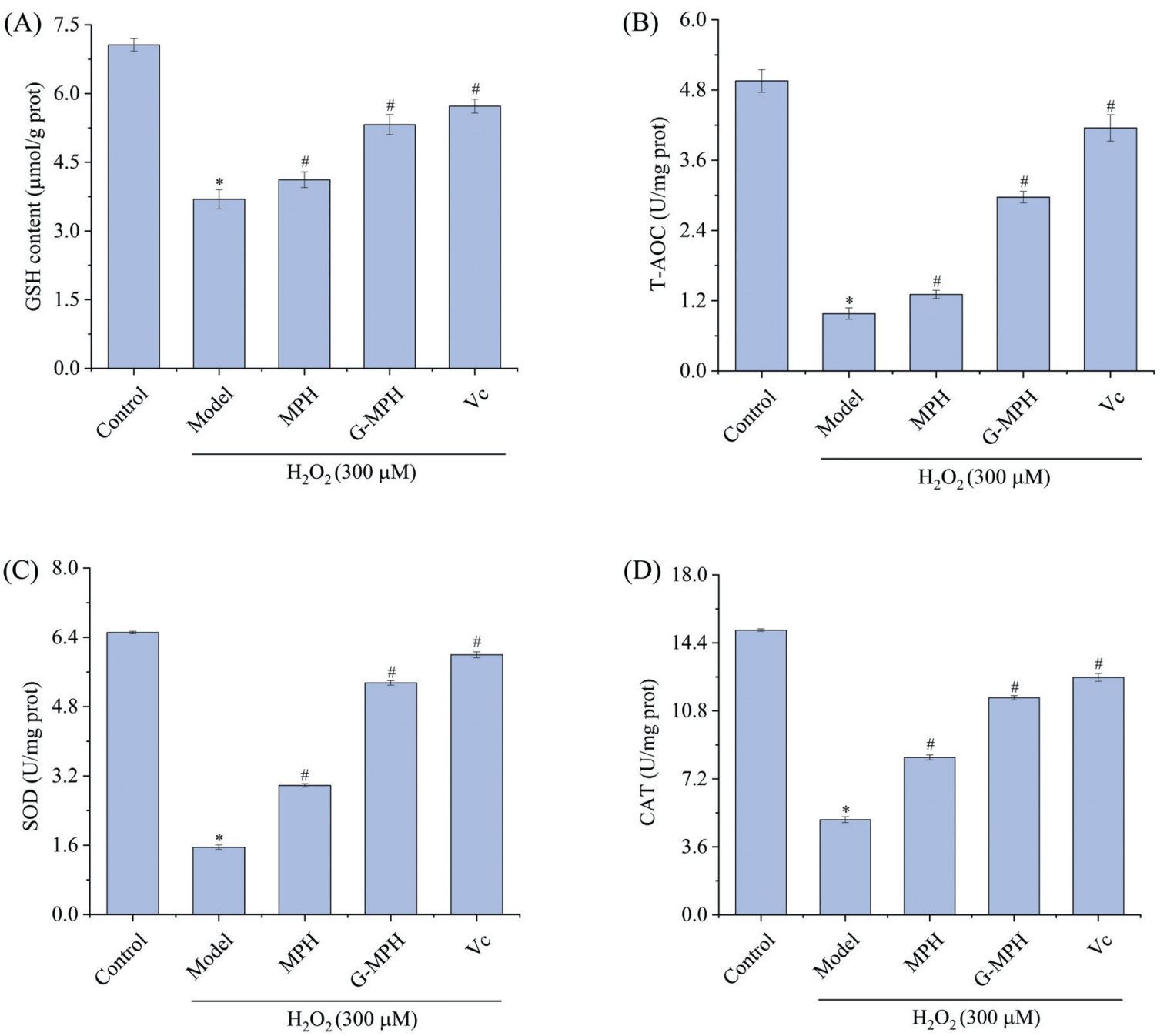

FIGURE 3. Effects of MPH and G-MPH on (A) glutathione (GSH) level, (B) total antioxidant capacity (T-AOC), (C) superoxide dismutase (SOD) activity, and (D) catalase (CAT) activity in $\mathrm{H}_{2} \mathrm{O}_{2}$-induced Caco-2 cells. All tested components were determined using the corresponding commercial assay kits. Data are means \pm SD from 3 independent experiments. ${ }^{*} p<0.05$ versus control, ${ }^{*} p<0.05$ versus model. MPH - Morchella protein hydrolysate; G-MPH - glycosylated derivative of MPH.

sumed by this defense system, which in turn protect cells from damage and maintain a stable state [Xu et al., 2016]. GSH, T-AOC, and antioxidant enzymes such as SOD and CAT play an extremely important role in the antioxidant defense system of cells. Therefore, these components were evaluated to investigate whether the protective effects of MPH and G$\mathrm{MPH}$ were associated with an improvement in antioxidant defense capacity of Caco-2 cells. After exposure to $300 \mu \mathrm{M}$ $\mathrm{H}_{2} \mathrm{O}_{2}$ for $6 \mathrm{~h}$, GSH level, T-AOC, and SOD and CAT activities were markedly decreased by $47.72 \%, 80.23 \%, 76.12 \%$, and $66.57 \%$, respectively, as compared to the control group $(p<0.05)$ (Figure 3$)$. As expected, compared with the model group, pretreatment of the cells with MPH and G-MPH significantly attenuated the decrease in the levels/activities of these components in $\mathrm{H}_{2} \mathrm{O}_{2}$-treated cells. Particularly, pretreatment of the cells with $\mathrm{G}-\mathrm{MPH}$ reversed the $\mathrm{H}_{2} \mathrm{O}_{2}$ -induced decrease in GSH levels by 1.44 folds (Figure $3 \mathrm{~A}$ ), T-AOC by 3.03 folds (Figure 3B), SOD activity by 3.44 folds (Figure 3C), and CAT activity by 2.28 folds (Figure 3D). However, the effects were not comparable to Vc. These data collectively indicate that MPH and G-MPH can exert their protective effects by improving the antioxidant defense capacity of Caco-2 cells. Results of the current study were similar to those of Shi et al. [2014], who found that eggshell membrane peptides protect Caco-2 cells from $\mathrm{H}_{2} \mathrm{O}_{2}$-induced oxidative damage by improving antioxidant enzyme activity and glutathione synthesis.

\section{Protective effects of MPH and G-MPH against oxidative injury involving activation of Nrf2 signaling pathway}

The Nrf2-antioxidant response element signaling pathway is a main endogenous antioxidant stress pathway that plays a key role in enhancing the antioxidant defense system of cells [Nguyen et al., 2009]. Nrf2, the main component of the signaling pathway, is normally located in the cytoplasm and combines with its cytosolic inhibitor, Keap-1. Various stimuli including oxidants, electrophiles, certain disease processes, and exogenous small (natural) molecules can activate Nrf2 through its disassociation from Keap-1. Activated Nrf2 translocates into the nucleus where it regulates the gene expression of phase II detoxifying and antioxidant enzymes to protect the organism from oxidative stress 

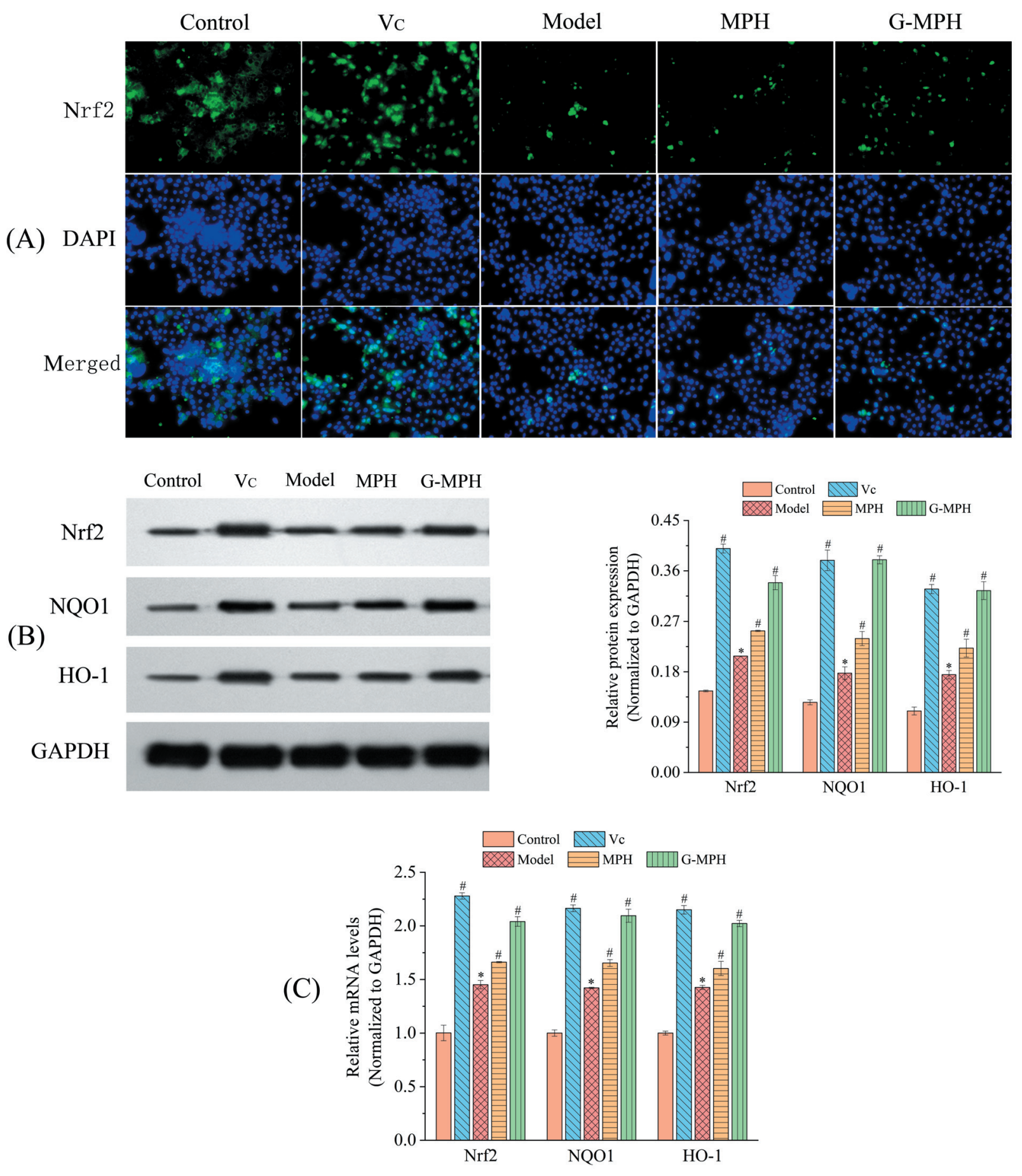

FIGURE 4. MPH and G-MPH activated Nrf2 signaling pathway in $\mathrm{H}_{2} \mathrm{O}_{2}$-treated Caco-2 cells. (A) Nrf2 nuclear translocation presented by immunofluorescence staining. Nrf2 was visualized using anti-Nrf2 antibody staining (shown in green) and nucleus was visualized using DAPI staining (shown in blue). Magnification: $\times 200$. (B) Protein levels of Nrf2, NQO1, and HO-1 analyzed by Western blot. All data were normalized to the loading control GAPDH. (C) mRNA levels of Nrf2, NQO1, and HO-1 quantified by qPCR. The results were normalized with GAPDH. Data are means \pm SD from 3 independent experiments. ${ }^{*} p<0.05$ versus control, ${ }^{*} p<0.05$ versus model. MPH - Morchella protein hydrolysate; G-MPH - glycosylated derivative of MPH.

and related injuries [Chang et al., 2018; Zhang et al., 2018a]. Activation of Nrf2 is considered as a therapeutic target for neurodegenerative and cardiovascular diseases [Cuadrado et al., 2009; Li et al., 2009].

To further elucidate the mechanisms underlying the cytoprotective effects of MPH and G-MPH, the impact on Nrf2 signaling pathway was investigated. The Nrf2 nuclear translocation detected by immunofluorescence (Figure 4A) showed that $\mathrm{Nrf} 2$ was mainly present in the cytoplasm of normal cells. $\mathrm{H}_{2} \mathrm{O}_{2}$-induced oxidative stress promoted partial translocation of Nrf2 into the nucleus, while pretreatment with MPH, G-MPH, or Vc significantly promoted the nuclear translocation of Nrf2. This result was coincident with those reported by Yang et al. [2017], who demonstrated that glycosylated fish protein hydrolysates induced nuclear translocation of Nrf2 to activate the Nrf2 signaling pathway. 

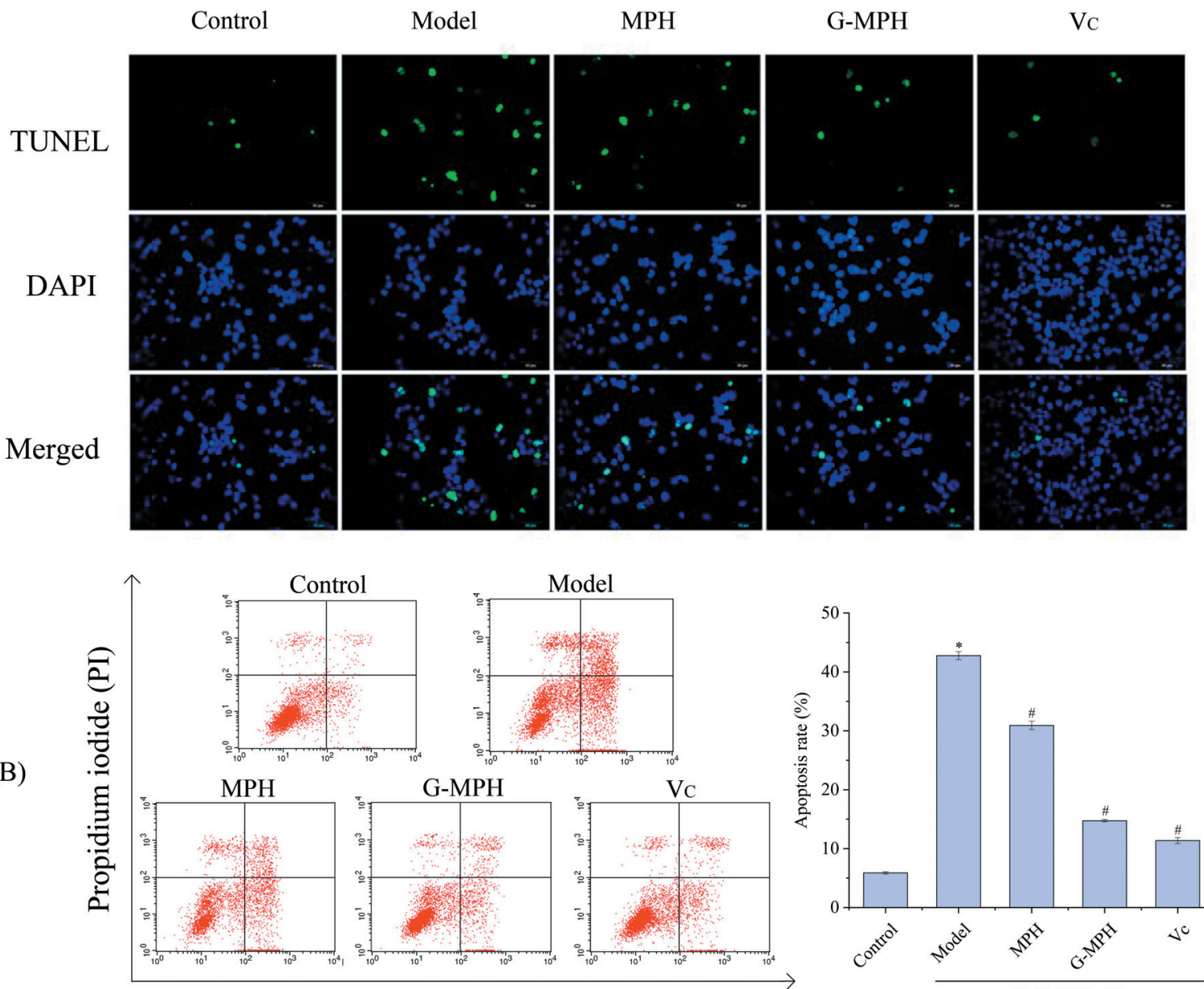

Annexin V-FITC

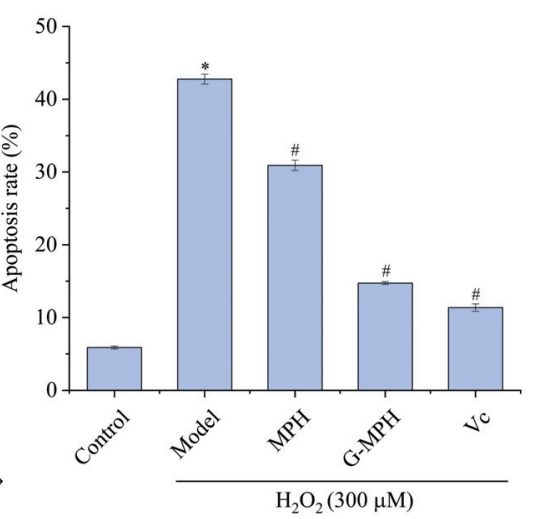

FIGURE 5. Effects of MPH and G-MPH on $\mathrm{H}_{2} \mathrm{O}_{2}$-induced apoptosis in Caco-2cells. (A) Cell apoptosis characterized by TUNEL assay ( $\times 200$ ). TUNEL (green) represents apoptotic cells, DAPI (blue) represents living cells. (B) Cell apoptosis detected by flow cytometry following Annexin V-FITC/ PI test. The upper and lower right quadrants of the dot plot indicate early apoptotic and late apoptotic cells, respectively. Apoptosis rate is the sum of early and late apoptosis values. The values are presented as means $\pm \mathrm{SD}, \mathrm{n}=3 .{ }^{*} p<0.05$ versus control, ${ }^{*} p<0.05$ versus model. MPH - Morchella protein hydrolysate; G-MPH - glycosylated derivative of MPH.

The effects of MPH and G-MPH on protein and mRNA expression of several components related to $\mathrm{Nrf2}$ signaling pathway including Nrf2, NQO1, and HO-1 were evaluated by Western blotting and qPCR, respectively. As shown in Figure 4B to C, the expressions of Nrf2, NQO1, and HO-1 at both protein and mRNA levels were significantly higher in the model group than in the control group after $\mathrm{H}_{2} \mathrm{O}_{2}$-induced oxidative damage $(p<0.05)$. This indicates that $\mathrm{H}_{2} \mathrm{O}_{2}$ activates $\mathrm{Nrf} 2$ antioxidant pathway while inducing oxidative stress. Compared with the model group, pretreatment with MPH, G-MPH, or Vc further increased the protein and mRNA expression levels of Nrf2, NQO1, and $\mathrm{HO}-1$ in the $\mathrm{H}_{2} \mathrm{O}_{2}$-treated Caco-2 cells. These data suggest that MPH and G-MPH may activate the Nrf2 signaling pathway which might serve as a crucial mechanism for MAP and G-MAP to exert their protective effects on cell oxidative stress. Similarly, Pyo et al. [2016] reported that glycosylated whey protein concentrate activated the Nrf2-dependent pathway and induced expressions of antioxidant enzymes and phase II enzymes that had cytoprotective effects against oxidative injury in HepG2 cells.
MPH and G-MPH ameliorated $\mathrm{H}_{2} \mathrm{O}_{2}$-induced apoptosis via restoring MMP and regulating apoptosis-related protein expression in Caco- 2 cells

Apoptosis is a mechanism which enables eukaryotic organisms to eliminate unwanted or defective cells through an orderly process of cell decomposition that is essential for the development of normal tissues [Li et al., 2016]. To maintain tissue homeostasis, a proper regulation of cell proliferation and apoptosis is critical [Pan et al. 2018]. To determine whether the protective effects of MPH and G-MPH against $\mathrm{H}_{2} \mathrm{O}_{2}$-induced injury were by counteracting apoptosis, the TUNEL staining and Annexin V/PI assay were performed to detect the apoptotic cells. TUNEL staining revealed that the number of TUNEL positive cells in the model group was notably increased in comparison with the control group. However, pretreatment with MPH, G-MPH, or Vc markedly decreased the number of TUNEL positive cells when compared with the model group (Figure 5A). At the same time, Annexin V/PI assay showed that the apoptosis rate was higher in the model group than that in the control group $(42.78 \pm 0.68 \%$ versus $5.88 \pm 0.19 \%)$. Moreover, when compared with model group, pretreatment with MPH, G-MPH, 
(A)

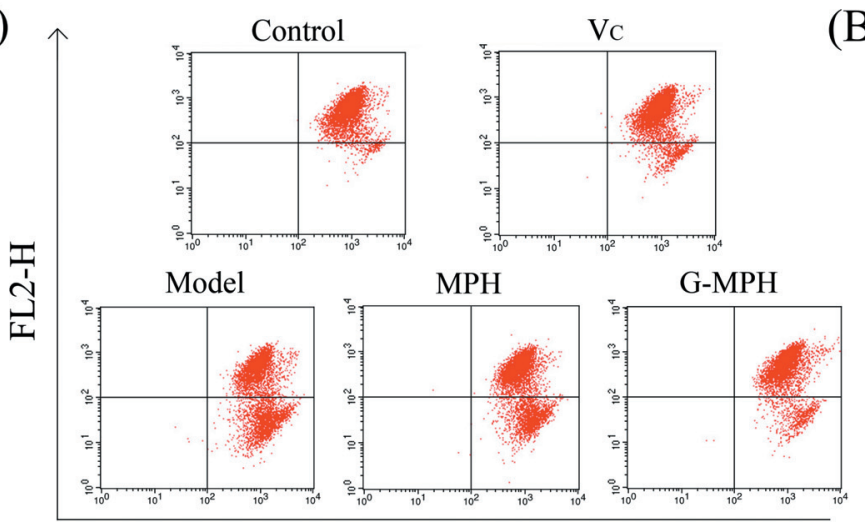

FL1-H
(B)

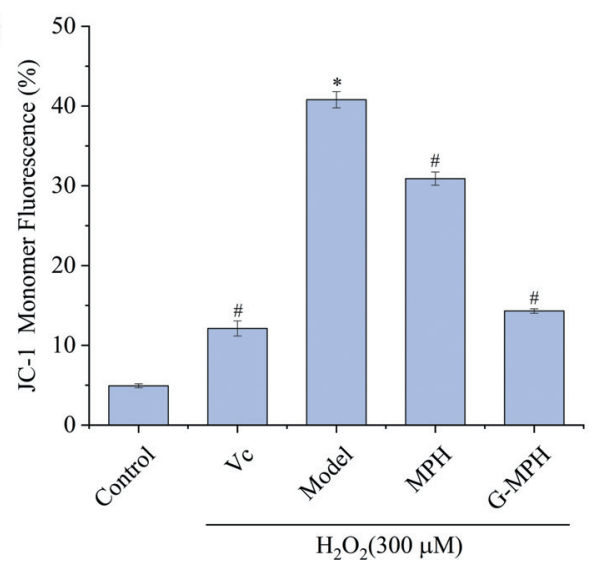

(C)

Bax

Bcl-2

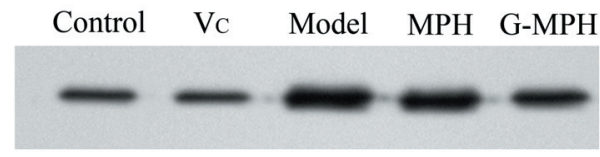

caspase-3

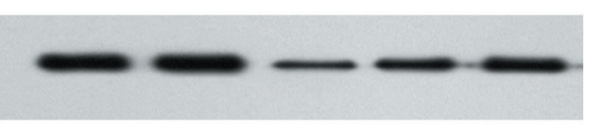

GAPDH
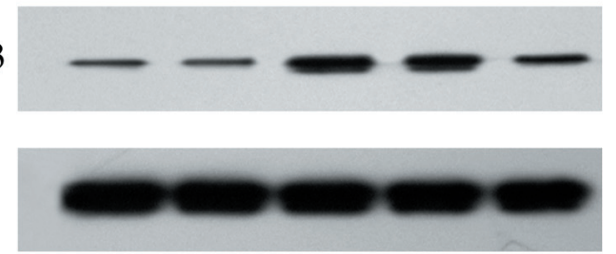

(D)

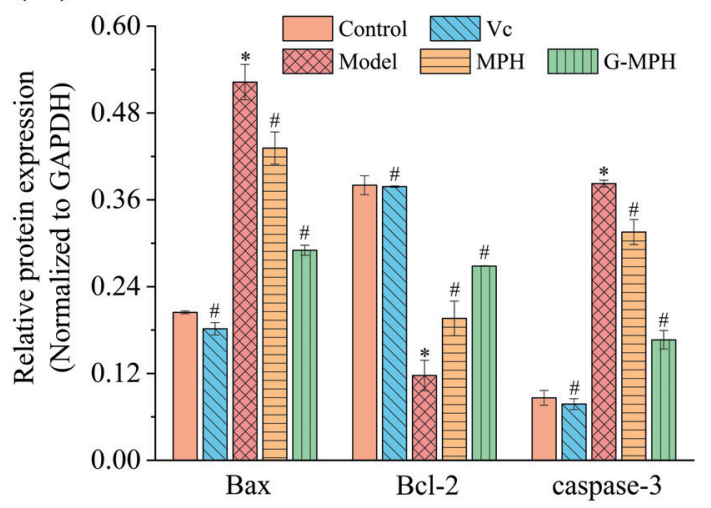

FIGURE 6. Effects of MPH and G-MPH on mitochondrial membrane potential (MMP) and expression levels of apoptosis related proteins. (A) The loss of MMP detected using flow cytometry after JC-1 staining. (B) The percentage of positive cells quantified. The increased JC-1 monomer ratio represents the loss of MMP. (C) Protein expressions of Bax, Bcl-2, and caspase-3 in Caco-2 cells analyzed by Western blot. (D) Quantification of Bcl-2, Bax, and caspase- 3 protein levels. The results were normalized with GAPDH. Data are means \pm SD from 3 independent experiments. * $p<0.05$ versus control, ${ }^{*} p<0.05$ versus model. MPH - Morchella protein hydrolysate; G-MPH - glycosylated derivative of MPH.

or Vc significantly decreased the apoptosis rate to $30.92 \pm 0.71$, $14.74 \pm 0.21$, and $11.37 \pm 0.51 \%$, respectively (Figure 5B). Apparently, these results suggest that MPH and G-MPH can exert potential protective effects against $\mathrm{H}_{2} \mathrm{O}_{2}$ injury through the inhibition of apoptosis.

Mitochondria play a crucial role in the process of cell apoptosis. The loss of MMP is regarded as an important signal for damage to mitochondrial structure. Therefore, we assessed whether MPH and G-MPH exerted anti-apoptotic effects by restoring MMP in Caco-2 cells using JC-1 assay. As shown in Figure 6A to B, a marked increase in the number of cells with low MMP was observed in the model group compared with the control group; however, the number of cells with low MMP was significantly decreased on pretreatment with $\mathrm{MPH}, \mathrm{G}-\mathrm{MPH}$, or $\mathrm{Vc}(30.90 \pm 0.63 \%$ for $\mathrm{MPH}, 14.30 \pm 0.28 \%$ for G-MPH, and $12.11 \pm 0.95 \%$ for $\mathrm{Vc}$ ) compared with the model group $(p<0.05)$. This indicated that MPH and G-MPH can restore MMP loss triggered by $\mathrm{H}_{2} \mathrm{O}_{2}$, stabilize mitochondrial function, and accordingly attenuate $\mathrm{H}_{2} \mathrm{O}_{2}$-induced apoptosis.

Apoptosis is regulated by the pro-apoptotic Bax and anti-apoptotic Bcl-2 proteins [Hu et al., 2015]. Increased Bax/
$\mathrm{Bcl}-2$ ratio (i.e., increased expression of Bax and reduced expression of $\mathrm{Bcl}-2$ ) is considered as a reliable indicator of apoptosis [Xue et al., 2014]. In addition, Caspase-3 is the primary executioner of apoptosis. Activation of caspase-3 triggers DNA fragmentation and chromatin condensation leading to an irreversible cascade of events progressing towards cell death [Liu et al., 2007; Neuzil et al., 2004]. To further understand the mechanisms via which MPH and G-MPH regulate cell apoptosis, the expression levels of apoptosis-related proteins including Bax, Bcl-2, and caspase-3 were investigated using Western blot analysis. Figure $6 \mathrm{C}$ shows the expression levels of proteins Bax, Bcl-2, and caspase-3 in each group presented by Western blots using GAPDH as an internal control. The corresponding quantitative results showed that the levels of Bax and caspase-3 were evidently increased, whereas the expression of $\mathrm{Bcl}-2$ was significantly reduced in the model group after $\mathrm{H}_{2} \mathrm{O}_{2}$ treatment when compared with the control group $(p<0.05)$. However, pretreatment with MPH, G-MPH, or $\mathrm{Vc}$ remarkably inhibited Bax and caspase- 3 expression and elevated Bcl-2 expression in comparison with the model group $(p<0.05)$ (Figure 6D). Thus, it suggests that the antiapoptotic effects of MPH and G-MPH are associated with 
the regulation of Bax, Bcl-2, and caspase- 3 protein expressions. As well, Jiao et al. [2018] confirmed that the cocaineand amphetamine-regulated transcript (CART) peptide can decrease the expression of Bax and caspase- 3 and increase the expression of $\mathrm{Bcl}-2$ to inhibit neuronal apoptosis while attenuating oxidative injury in rat hippocampal neurons.

\section{CONCLUSIONS}

In the present study, the cytoprotective effects of MPH and G-MPH against oxidative stress and their underlying mechanisms were assessed in Caco-2 cells. MPH and G-MPH attenuated $\mathrm{H}_{2} \mathrm{O}_{2}$-induced cytotoxicity in Caco-2 cells and exhibited protective effects by inhibiting the productions of ROS and MDA, enhancing antioxidant defense capacity, and activating $\mathrm{Nrf} 2$ signaling pathway under $\mathrm{H}_{2} \mathrm{O}_{2}$-induced oxidative stress. Moreover, MPH and G-MPH prevented $\mathrm{H}_{2} \mathrm{O}_{2}$-induced apoptosis by restoring the loss of MMP and regulating the expression of apoptosis-related proteins. Collectively, MPH and G-MPH can protect Caco-2 cells against $\mathrm{H}_{2} \mathrm{O}_{2}$-induced oxidative injury via elevating antioxidant response and inhibiting apoptosis. Therefore, the current research suggests that MPH and G-MPH can be excellent nutraceutical/functional food components or potential therapeutic agents to prevent or treat oxidative stress-induced diseases.

\section{RESEARCH FUNDING}

This work was supported by the grant from the Doctorate Fellowship Foundation of Nanjing Forestry University (2014), the Natural Science Foundation of Anhui Provincial Department of Education (Project No. KJ2017A515), the Postgraduate Research \& Practice Innovation Program of Jiangsu Province (Project No. KYLX15_0916), the Natural Science Foundation of Jiangsu province (Project No. BK20150883), and the Priority Academic Program Development of Jiangsu Higher Education Institutions (PAPD).

\section{CONFLICT OF INTERESTS}

The authors declare no conflict of interest.

\section{REERENCES}

1. Chang, H.T., Jan, C.R., Liang, W.Z. (2018). Protective effects of a phenolic glycoside compound curculigoside on $\mathrm{H}_{2} \mathrm{O}_{2}$-induced oxidative stress and cytotoxicity in normal human breast epithelial cells. Journal of Functional Foods, 41, 171-182.

2. Chen, J.C., Wang, R.F., Wang, T.Y., Ding, Q.L., Khalil, A., Xu, S.T., Lin, A.J., Yao, H.Q., Xie, W.J., Zhu, Z.Y., Xu, J.Y., (2017). Antioxidant properties of novel dinners derived from natural beta-elemene through inhibiting $\mathrm{H}_{2} \mathrm{O}_{2}$-induced apoptosis. ACS Medicinal Chemistry Letters, 8(4), 443-448.

3. Cuadrado, A., Moreno-Murciano, P., Pedraza-Chaverri, J. (2009). The transcription factor Nrf2 as a new therapeutic target in Parkinson's disease. Expert Opinion on Therapeutic Targets, 13(3), 319-329.

4. Desagher, S., Martinou, J.C. (2000). Mitochondria as the central control point of apoptosis. Trends in Cell Biology, 10(9), 369-377.
5. Fernandez-Checa, J.C., Fernandez, A., Morales, A., Mari, M., Garcia-Ruiz, C., Colell, A. (2010). Oxidative stress and altered mitochondrial function in neurodegenerative diseases: Lessons from mouse models. CNS \& Neurological Disorders - Drug Targets, 9(4), 439-454.

6. Hu, J., Yu, Q. W., Zhao, F., Ji, J. Z., Jiang, Z. Z., Chen, X., Gao, P., Ren, Y.R., Shao, S., Zhang, L.Y., Yan, M. (2015). Protection of quercetin against triptolide-induced apoptosis by suppressing oxidative stress in rat Leydig cells. Chemico-Biological Interactions, 240, 38-46.

7. Je, J.Y., Lee, D.B. (2015). Nelumbo nucifera leaves protect hydrogen peroxide-induced hepatic damage via antioxidant enzymes and HO-1/Nrf2 activation. Food \& Function, 6(6), 1911-1918.

8. Jiao, W., Wang, Y., Kong, L., Ou-yang, T., Meng, Q., Fu, Q., Hu, Z.Z. (2018). CART peptide activates the Nrf2/HO-1 antioxidant pathway and protects hippocampal neurons in a rat model of Alzheimer's disease. Biochemical and Biophysical Research Communications, 501 (4), 1016-1022.

9. Jin, M.M., Zhang, L., Yu, H.X., Meng, J., Sun, Z., Lu, R.R. (2013). Protective effect of whey protein hydrolysates on $\mathrm{H}_{2} \mathrm{O}_{2}$ -induced PC12 cells oxidative stress via a mitochondria-mediated pathway. Food Chemistry, 141(2), 847-852.

10. Lee, J.Y., Lee, S.H., Kim, H.J., Ha, J.M., Lee, S.H., Lee, J.H., Ha, B.J. (2004). The preventive inhibition of chondroitin sulfate against the $\mathrm{CCl}_{4}$-induced oxidative stress of subcellular level. Archives of Pharmacal Research, 27(3), 340-345.

11. Li, J.Q., Ichikawa, T., Janicki, J.S., Cui, T.X. (2009). Targeting the Nrf2 pathway against cardiovascular disease. Expert Opinion on Therapeutic Targets, 13(7), 785-794.

12. Li, T.G., Chen, B., Du, M., Song, J.J., Cheng, X., Wang, X., Mao, X. (2017). Casein glycomacropeptide hydrolysates exert cytoprotective effect against cellular oxidative stress by up-regulating HO-1 expression in HepG2 cells. Nutrients, 9(1), art. no. 31.

13. Li, Y., Li, J.H., Huang, H., Yang, M.F., Zhuang, D.G., Cheng, X.M., Zhang, H.Z., Fu, X.L. (2016). Microcystin-LR induces mitochondria-mediated apoptosis in human bronchial epithelial cells. Experimental and Therapeutic Medicine, 12(2), 633-640.

14. Liu, C.L., Xie, L.X., Li, M., Durairajan, S.S. K., Goto, S., Huang, J.D. (2007). Salvianolic acid B inhibits hydrogen peroxide-induced endothelial cell apoptosis through regulating PI3K/Akt signaling. PLoS One, 2(12), art. no. e1321.

15. Mańdziuk, S., Dudzisz-Sledź, M., Korszeń-Pilecka, I., Milanowski, J., Wojcierowski, J., Korobowicz, E. (2003). Expression of 553 gene in stage IIIA non-small cell lung cancer in patients after neoadjuvant chemotherapy with Vepesid and Cisplatin. Annales Universitatis Mariae Curie-Sklodowska. Sectio D: Medicina, 58(1), 154-157.

16. Mariani, E., Polidori, M.C., Cherubini, A., Mecocci, P. (2005). Oxidative stress in brain aging, neurodegenerative and vascular diseases: An overview. Journal of Chromatography. B, Analytical Technologies in the Biomedical and Life Sciences, 827(1), 65-75.

17. Morifuji, M., Ishizaka, M., Baba, S., Fukuda, K., Matsumoto, H., Koga, J., Kanegae, M., Higuchi, M. (2010). Comparison of different sources and degrees of hydrolysis of dietary protein: Effect on plasma amino acids, dipeptides, and insulin responses in human subjects. Journal of Agricultural and Food Chemistry, 58(15), 8788-8797.

18. Neuzil, J., Tomasetti, M., Mellick, A.S., Alleva, R., Salvatore, B.A., Birringer, M., Fariss, M.W. (2004). Vitamin E analogues: 
A new class of inducers of apoptosis with selective anti-cancer effects. Current Cancer Drug Targets, 4(4), 355-372.

19. Nguyen, T., Nioi, P., Pickett, C.B. (2009). The Nrf2-antioxidant response element signaling pathway and its activation by oxidative stress. The Journal of Biological Chemistry, 284(20), 13291-13295 .

20. Pan, W.J., Ding, Q.Y., Wang, Y., Wang, D.D., Lu, Y.M., Yang, W.W., Cai, Z.N., Cheng, X.D., Zhang, W.N., Chen, Y. (2018). A bioactive polysaccharide TLH-3 isolated from Tricholoma lobayense protects against oxidative stress-induced premature senescence in cells and mice. Journal of Functional Foods, 42, 159-170.

21. Pyo, M.C., Yang, S.Y., Chun, S.H., Oh, N.S., Lee, K.W. (2016). Protective effects of Maillard reaction products of whey protein concentrate against oxidative stress through an Nrf2-dependent pathway in HepG2 cells. Biological \& Pharmaceutical Bulletin, 39(9), 1437-1447.

22. Ruiz-Roca, B., Delgado-Andrade, C., Navarro, M.P., Seiquer, I. (2011). Effects of Maillard reaction products from glucose-lysine model systems on oxidative stress markers and against oxidative induction by hydrogen peroxide in Caco-2 cells. Journal of Food and Nutrition Research, 50(4), 237-248.

23. Seifried, H.E., Anderson, D.E., Fisher, E.I., Milner, J.A. (2007). A review of the interaction among dietary antioxidants and reactive oxygen species. The Journal of Nutritional Biochemistry, 18(9), 567-579.

24. Shen, R., Liu, D.S., Hou, C.C., Liu, D., Zhao, L.X., Cheng, J., Wang, D.G., Bai, D.C., (2017). Protective effect of Potentilla anserina polysaccharide on cadmium-induced nephrotoxicity in vitro and in vivo. Food \& Function, 8(10), 3636-3646.

25. Shi, Y.N., Kovacs-Nolan, J., Jiang, B., Tsao, R., Mine, Y. (2014). Peptides derived from eggshell membrane improve antioxidant enzyme activity and glutathione synthesis against oxidative damage in Caco-2 cells. Journal of Functional Foods, 11, 571-580.

26. Wang, Z.J., Xie, J.H., Kan, L.J., Wang, J.Q., Shen, M.Y., Li, W.J., Nie, S.P., Xie, M.Y., (2015). Sulfated polysaccharides from $C y$ clocarya paliurus reduce $\mathrm{H}_{2} \mathrm{O}_{2}$-induced oxidative stress in RAW 264.7 cells. International Journal of Biological Macromolecules, 80, 410-417.

27. Xia, T., Yao, J.H., Zhang, J., Zheng, Y., Song, J., Wang, M. (2017). Protective effects of Shanxi aged vinegar against hydrogen peroxide-induced oxidative damage in LO2 cells through Nrf2-mediated antioxidant responses. RSC Advances, 7(28), 17377-17386.

28. Xu, Z., Fang, Y., Chen, Y., Yang, W.J., Ma, N., Pei, F., Kimatu, B.M., Hu, Q.H., Qiu, W.F., (2016). Protective effects of Se-containing protein hydrolysates from Se-enriched rice against $\mathrm{Pb}^{2+}$ induced cytotoxicity in PC12 and RAW264.7 cells. Food Chemistry, 202, 396-403.

29. Xue, S., Chen, Y.X., Qin, S.K., Yang, A.Z., Wang, L., Xu, H.J., Geng, H.Y. (2014). Raltitrexed induces mitochondrial-mediated apoptosis in SGC7901 human gastric cancer cells. Molecular Medicine Reports, 10(4), 1927-1934.
30. Yamaguchi, M., Okamoto, K., Kusano, T., Matsuda, Y., Suzuki, G., Fuse, A., Yokota, H. (2015). The effects of xanthine oxidoreductase inhibitors on oxidative stress markers following global brain ischemia reperfusion injury in C57BL/6 mice. PLoS One, 10(7), art. no. e0133980.

31. Yang, S.Y., Lee, S., Pyo, M.C., Jeon, H., Kim, Y., Lee, K.W. (2017). Improved physicochemical properties and hepatic protection of Maillard reaction products derived from fish protein hydrolysates and ribose. Food Chemistry, 221, 1979-1988.

32. Yoon, S.O., Kim, M.M., Park, S.J., Kim, D., Chung, J., Chung, A.S. (2001). Selenite suppresses hydrogen peroxide-induced cell apoptosis through inhibition of ASK1/JNK and activation of PI3-K/Akt pathways. The FASEB Journal, 15(13), 111-113.

33. Zamora-Sillero, J., Ramos, P., Monserrat, J.M., Prentice, C. (2018). Evaluation of the antioxidant activity in vitro and in hippocampal HT-22 cells system of protein hydrolysates of common carp (Cyprinus carpio) by-product. Journal of Aquatic Food Product Technology, 27(1), 21-34.

34. Zha, F.C., Wei, B.B., Chen, S.J., Dong, S.Y., Zeng, M.Y., Liu, Z.Y. (2015). The Maillard reaction of a shrimp by-product protein hydrolysate: Chemical changes and inhibiting effects of reactive oxygen species in human HepG2 cells. Food \& Function, 6(6), 1919-1927.

35. Zhang, H.J., Chen, R.C., Sun, G.B., Yang, L.P., Xu, X.D., Sun, X.B. (2018a). Protective effects of total flavonoids from Clinopodium chinense (Benth.) O. Ktze on myocardial injury in vivo and in vitro via regulation of Akt/Nrf2/HO-1 pathway. Phytomedicine, 40, 88-97.

36. Zhang, Q., Wu, C.E., Fan, G.J., Li, T.T., Sun, Y.J. (2018b). Improvement of antioxidant activity of Morchella esculenta protein hydrolysate by optimized glycosylation reaction. CyTA - Journal of Food, 16(1), 238-246.

37. Zhang, Q., Wu, C.E., Fan, G.J., Li, T.T., Wen, X. (2018c). Characteristics and enhanced antioxidant activity of glycated Morchella esculenta protein isolate. Food Science and Technology (Campinas), 38(1), 126-133.

38. Zhang, Q.Z., Tong, X.H., Sui, X.N., Wang, Z.J., Qi, B.K., Li, Y., Jiang, L.Z. (2018d). Antioxidant activity and protective effects of alcalase-hydrolyzed soybean hydrolysate in human intestinal epithelial Caco-2 cells. Food Research International, 111, 256-264.

39. 39 Zhang, X.X., Wang, L., Wang, R., Luo, X.H., Li, Y.A., Chen, Z.X. (2016). Protective effects of rice dreg protein hydrolysates against hydrogen peroxide-induced oxidative stress in HepG2 cells. Food \& Function, 7(3), 1429-1437.

40. Zhou, Y.F., Guo, B., Ye, M.J., Liao, R.F., Li, S.L. (2016). Protective effect of rutin against $\mathrm{H}_{2} \mathrm{O}_{2}$-induced oxidative stress and apoptosis in human lens epithelial cells. Current Eye Research, 41(7), 933-942.

Submitted: 17 April 2019. Revised: 12 June 2019. Accepted: 19 June 2019. Published on-line: 5 July 2019. 
